DOI https://doi.org/10.30525/978-9934-588-80-8-2.15

\title{
НОВІ МЕТОДИ ПІДГОТОВКИ ФАХІВЦІВ
}

\author{
Мовчан Л. В. \\ кандидат педагогічних наук, дочент, \\ старший викладач кафедри української та іноземних мов \\ Уманський національний університет садівництва \\ Комісаренко Н. О. \\ кандидат педагогічних наук, дочент, \\ завідувач кафедри украӥнської та іноземних мов \\ Уманський національний університет садівниитва \\ м. Умань, Черкаська область, Україна
}

Швидкий розвиток суспільства вимагає докорінних змін в усіх сферах життєдіяльності людей де освіта не є винятком. Система освіти України наразі проходить новий період реформування і перебудови. Перед університетами постають нові виклики суспільства: підготувати фахівців, спроможних критично мислити, творчо вирішувати проблеми, працювати в команді. У міру поширення інформації та фактів здатність орієнтуватися в широкому діапазоні дисциплін та критично оцінювати будь-яку інформацію стає важливими атрибутами успіху в сучасному суспільстві. Все частіше найважливішим елементом сучасної педагогічної освіти $\epsilon$ вміння студентів думати і діяти як експерти, використовуючи оригінальні ідеї, цінні знання та нестандартний підхід до вирішення проблеми на благо своєї країни.

Провідні університети розуміють, що їм потрібно змінити педагогіку 3 традиційних лекцій, заснованих на фактах, на інтерактивне викладання 3 метою виховання стійких навичок, таких як критичне мислення, розвиток та набуття експертного мислення та вирішення проблем. В інтерактивному режимі навчання студенти будуть більш рівноправними учасниками викладання, заснованого на дослідженнях, в процесі виявлення, інновацій та навчання через помилки. Один із наслідків полягає в тому, що вони навчаться діяти і мислити як експерти, а також матимуть краще уявлення про професійну ідентичність.

Головна мета інноваційної освіти - збереження і розвиток творчого потенціалу людини. Проте сьогодні недостатньо творчості та проектування. Освіту потрібно сприйняти як загальнолюдську цінність. Для цього,насамперед, необхідно зробити так, щоб вона розвивала 
гармонійне мислення, побудоване на поєднанні внутрішньої свободи особистості та іiі соціальної відповідальності, а також терпимості до інакомислення.

Інноваційне навчання - це постійне прагнення до переоцінки цінностей, збереження тих із них, які мають незаперечне значення і відкидання тих, що вже застаріли. Інновації у навчальній діяльності пов'язані 3 активним процесом створення, поширення нових методів і засобів для вирішення дидактичних завдань підготовки фахівців у гармонійному поєднанні класичних традиційних методик та результатів творчого пошуку, застосування нестандартних, прогресивних технологій, оригінальних дидактичних ідей і форм забезпечення освітнього процесу $[2,14]$.

Майкл Гадзон, старший науковий консультант Pearson вважає: «... все, що ми робимо в класі, повинно мати за мету підготувати наших студентів до речей, які їм доведеться робити у зовнішньому світі, і тому я є великим захисником навчання на практиці. Моє завдання як вчителя полягає не у визначенні єдиного способу щось робити, а в тому, щоб полегшити можливості студентам домовлятися та досліджувати різні способи досягнення однієї мети та допомогти їм зробити оптимальні висновки.

У сучасному світі 3 таким простим доступом до інформації, наші студенти мають всі знання, яких вони могли б потребувати, буквально під рукою. Те, що їм все ще потрібно - це досвідчений гід. Існує міф про те, що сучасні студенти університету не хочуть вчитися. Натомість вони просто не хочуть вивчати те, що їм вказують певні установи. Ми мусимо співстворити свої лекції зі студентами, а також маємо бути вневненими, що вони активно спілкуються мовою як в адиторії, так і поза нею. Звичайно, це не простий процес, бо від викладачів є певні очікування стосовно того що, як і коли вони викладають. Тому дуже важливо створити мережі, де вчителі можуть поділитися досвідом та дізнатись, як застосовуються різні підходи як тут, так і по всьому світу» [1].

На даний час все частіше використовуються сучасні стратегії викладання, гармонійне поєднання з традиційними методами, які необхідні для гарної підготовки студента / науковця. Яковлєва Н. та Яковлєв Е. розповідають про використання інтерактивних методів навчання, що стимулюють інтерес до професії; сприяють ефективному придбанню навчальних матеріалів; формують зразки поведінки; забезпечують високу мотивацію, силу, знання, командний дух та свободу вираження поглядів; і головне, вносять свій доробок у складні компетенції майбутніх фахівців. Вони визначили такі методи навчання: тренінг, метод кейсів, поведінкове моделювання, ігрові проекти, метод зворотного зв'язку, гра в метафори, розповідь розповідей, метод навчання дії, 
метод кошика. Науковці зазначили, що активні методи навчання змінюють роль викладача від перекладача інформації до організатора та координатора навчального процесу та дають змогу формувати складні компетентності у майбутніх професійних спеціальностях завдяки діяльності студентів, яка максимально точно виявляє зміст професійної роботи [3].

Бурнер Т. (Bourner T.) та Флауерс C.(Flowers S). зазначають, що університети мають два основні процеси: викладання та дослідження. Результатом викладання $\epsilon$ навчання, а результатом дослідження $\epsilon$ внесок у знання. Вони чітко бачать цілі навчання вищої освіти: поширювати знання; розвивати здатність використовувати ідеї та інформацію; розвивати у студентів здатність перевіряти ідеї та докази; розвивати вміння студента генерувати ідеї та докази; сприяти особистісному розвитку студента; розвивати здатність студентів планувати та керувати власним навчанням. Вони вважали, що якість освіти визначається 3 точки зору всіх цих цілей. Кожна 3 потенційних цілей навчання пропонує широкий спектр методів навчання для досягнення якісного результату.

Отже, різні методи навчання підходять для різних цілей навчання:

1. Поширювати знання: лекції, сучасні підручники, читання, роздатковий матеріал, «гостьові» лекції, використання вправ, які вимагають від студентів знаходження сучасних знань, формування навичок користування бібліотекою та іншими навчальними ресурсами, спрямованих на приватне навчання, відкриті навчальні матеріали, користування Інтернетом.

2. Розвивати здатність використовувати ідеї та інформацію: тематичні дослідження, практичні заняття, досвід роботи, проекти, демонстрації, групова робота, моделювання (наприклад, на комп’ютері), семінари, дискусії та дебати, есе, письмо.

3. Розвивати здатність студента перевіряти ідеї та докази: семінари та навчальні посібники, презентації, есе, відгуки про письмові роботи, рецензування літератури, екзаменаційні роботи, відкрите навчання, експертна оцінка, самооцінка.

4. Розвивати здатність студента генерувати ідеї та докази: дослідницькі проекти, практикуми 3 техніки творчого вирішення проблем, групової роботи, навчання діям, всебічного мислення, мозкового штурму, картографування розуму, творчої візуалізації, коучингу, вирішення проблем.

5. Сприяти особистісному розвитку студентів: зворотний зв'язок, експериментальне навчання, навчальні контракти, дієве навчання, 
рольові ігри, структурований досвід у групах, відображальні документи, самооцінка, профілювання.

6. Розвивати здатність студентів планувати та управляти власним навчанням: навчальні контракти, проекти, навчальні дії, семінари, наставники, відображальні журнали та щоденники, незалежне навчання, працевлаштування, розробка портфоліо, дисертації [4].

Таким чином, сьогодні мисляча людина зобов'язана спостерігати, аналізувати, вносити пропозиції, відповідати за ухвалені рішення й уміти долати конфлікти й суперечності. А для цього вона повинна мати культуру, багатокритерійну установку розв'язання завдань, а також розуміти, що ніхто не може претендувати на істину в останній інстанції і жодну теорію не можна вважати універсальною і вічною. Головний принцип інноваційної освіти полягає в тому, що вона скерована на формування світогляду, основаного на багатокритерійності рішень, терпимості до інакомислення й відповідальності за свої дії.

\section{Література:}

1. Майкл Гадзон. Сучасні методи викладання - необхідна умова розвитку університетів. Режим доступу: http://gohigher.org/suchansimetody-vykladannya-neobhodna-umova-rozvytku-universytetiv)

2. Інновації у вищій освіті: проблеми, досвід, перспективи. Монографія / П. Ю. Саух [та ін.]; ред. П. Ю. Саух. - Житомир: Вид-во ЖДУ ім. І. Франка, 2011. - С. 14, 319.

3. Bourner and Tom Steve Flowers. (2001). Teaching and Learning Methods in Higher Education: a glimpse of the future. Retrieved from http://www.bbk.ac.uk/asd/bourne.htm

4. Yakovleva O. V., Yakovlev E. V. (2014) Interactive teaching methods in contemporary higher education. Pacific Science Review, 16, $75-80$. 